\title{
Phenotypic Variation of Pseudomonas brassicacearum as a Plant Root-Colonization Strategy
}

\author{
Wafa Achouak, Sandrine Conrod, Valérie Cohen, and Thierry Heulin \\ Laboratoire d'Écologie Microbienne de la Rhizosphère (LEMiR), UMR 6191 CNRS-CEA-Université Aix-Marseille II, \\ DEVM-DSV, IFR 112 PMSE, CEA Cadarache, F-13108 Saint-Paul-lez-Durance, France
}

Submitted 30 June 2003. Accepted 29 March 2004.

\begin{abstract}
Pseudomonas brassicacearum was isolated as a major rootcolonizing population from Arabidopsis thaliana. The strain NFM421 of $P$. brassicacearum undergoes phenotypic variation during $A$. thaliana and Brassica napus root colonization in vitro as well as in soil, resulting in different colony appearance on agar surfaces. Bacteria forming translucent colonies (phase II cells) essentially were localized at the surface of young roots and root tips, whereas wild-type cells (phase I cells) were localized at the basal part of roots. The ability of phase II cells to spread and colonize new sites on root surface correlates with over-production of flagellin as evidenced by sodium dodecyl sulfate-polyacrylamide gel electrophoresis analysis of surface proteins and microsequencing. Moreover, phase II cells showed a higher ability to swim and to swarm on semisolid agar medium. Phase I and phase II cells of $P$. brassicacearum NFM421 were tagged genetically with green fluorescent protein and red fluorescent protein. Confocal scanning laser microscopy was used to localize phase II cells on secondary roots and root tips of $A$. thaliana, whereas phase I cells essentially were localized at the basal part of roots. These experiments were conducted in vitro and in soil. Phenotypic variation on plant roots is likely to be a colonization strategy that may explain the high colonization power of $\boldsymbol{P}$. brassicacearum.
\end{abstract}

Additional keywords: co-localization, rhizosphere.

The rhizosphere is the soil zone submitted to the influence of plant roots. It is a rich ecological niche highly coveted by soil microorganisms which may use root exudates as energy and carbon sources. However, the rhizosphere bacteria have to compete with each other for nutrients and for colonization sites on the roots. Rhizobacteria may undergo damage due to plant defense that they may themselves induce, compete with other microorganisms, and colonize or even invade root tissues, resulting in pathologic interactions, symbioses, or beneficial associations.

Rhizosphere soil osmolarity is expected to be elevated as a result of the release of plant root exudates (Miller and Wood 1999). The survival of bacterial strains in such an environment depends on their ability to adapt to these conditions. Hence, microorganisms have evolved different strategies to respond and adapt to changing environments (e.g., by phenotypic variation, which is an adaptive process by which bacteria undergo frequent and often reversible phenotypic changes resulting

Corresponding author: Wafa Achouak; Telephone: (33) 442254 961; Fax: (33) 442256 648; E-mail: wafa.achouak@cea.fr from genetic or epigenetic alterations in specific loci of their genomes). Varying the expression of some structures can allow bacteria to colonize new ecological niches and to escape host defenses (Hallet 2001). Phenotypic variation can be detected as spontaneous reversible differences in colony morphology (Shapiro 1986). Such variation often affects the surface structures involved in pathogen adherence, colonization, or immune invasion (Hosking et al. 1999; Zhang and Wise 1996).

Phenotypic variation generates diversity within a clonal bacterial population, leading to subpopulations expressing different surface structures, such as fimbriae of Escherichia coli, flagella of Salmonella typhimurium (Pearce and Stocker 1967), Opa proteins of Neisseria (Makino et al. 1991), or lipoproteins of Borrelia spp. (Barbour et al. 1982; Howe et al. 1986; Zhang et al. 1997). Various mechanisms control the phenotypic variation (e.g., DNA inversion or duplication, transposition, homologous recombination, slipped-strand mispairing, and differential methylation) (Hallet 2001; Henderson et al. 1999).

Phenotypic switching in colonies of the causal agent of brown blotch disease in mushrooms, Pseudomonas tolaasii, has been described (Cutri et al. 1984; Grewal et al. 1995). Phase variants also appear in $P$. aeruginosa during biofilm formation (Déziel et al. 2001) and, more recently, Drenkard and Ausubel (2002) showed that Pseudomonas biofilm formation and antibiotic resistance were linked to phenotypic variation. Phenotypic variation is not restricted to pathogenic bacteria. When $P$. fluorescens SBW25 was grown in static liquid medium, three subpopulations arose and occupied different parts of the culture: surface, middle part, and bottom (Rainey and Travisano 1998). These subpopulations did not appear in a homogeneous environment such as a shaken liquid culture. Phenotypic variation of $P$. fluorescens F113 occurs during alfalfa root colonization (Sánchez-Contreras et al. 2002). A mutation in the sss gene encoding a site-specific recombinase affects competitive root colonization by $P$. fluorescens WCS365. As in other species, this gene is implicated in phase variation; an implication of phase variation in plant-rhizobacteria interaction has been suggested (Dekkers et al. 1998). Moreover, more recently, the regulation of biocontrol traits by phase variation was reported for some Pseudomonas spp. strains isolated from maize rhizosphere (van den Broek et al. 2003). These studies emphasized the importance of phenotypic variation in the ecology of soil bacteria.

We previously reported phenotypic variation affecting colony morphology and exoenzyme production in the rhizospherecolonizing bacterium P. brassicacearum NFM421 (Chabeaud et al. 2001). Strains of $P$. brassicacearum were isolated as the major root colonizers of Arabidopsis thaliana Col growing in four different soils where this plant grows naturally (Achouak 
et al. 2000). P. brassicacearum represented up to $10 \%$ of total culturable bacteria associated with $A$. thaliana roots and up to $60 \%$ of those associated with Brassica napus roots. This rhizobacterium is studied for its interaction with $A$. thaliana (Persello-Cartieaux et al. 2001) and for its properties as an antifungal biocontrol agent (Ross et al. 2000). Efficient antifungal biocontrol requires a high colonization ability of the selected rhizobacteria. The main criteria that we used for isolation of bacteria from A. thaliana roots were a high frequency and a great colonization efficiency of these bacteria.

The aim of this study was to investigate the mechanism of A. thaliana root colonization by $P$. brassicacearum NFM421 and to explore the role of phase variation in this plant-microbe interaction. In this work, we report the ability of $P$. brassicacearum NFM421 to undergo phenotypic variation during $A$. thaliana root colonization. The colonization pattern by both variants of this bacterium was determined by their co-localization on root system in vitro as well as in soil. This is the first report showing an in planta co-localization of a rhizobacterium and its phenotypic variant, during $A$. thaliana root colonization.

\section{RESULTS}

$P$. brassicacearum was isolated from $A$. thaliana rhizosphere as the frequent and major root-colonizing bacterial population. The strain NFM421 has the property to form phenotypic variants when grown on rich media (Chabeaud et al. 2001). In the present study, we investigated the role of this phenomenon in the interaction of this bacterium with $A$. thaliana.

\section{Kinetics of root colonization.}

Five sterilized seeds of $A$. thaliana were laid on an agar band containing $10^{2}$ CFU of phase I cells of strain NFM421. The colonization kinetics were determined by counting bacteria attached to plant roots after grinding and plating serial dilutions of crushed roots over time. At the expense of root exudates, bacteria actively grew and reached up to 17 generations within 4 weeks, as the number of total bacteria exceeded $10^{7}$ CFU per root system (Fig. 1), whereas each seed was in contact with almost 10 bacteria before germination.

\section{Phenotypic variation in planta.}

Phenotypic variation of $P$. brassicacearum NFM421 colonizing roots was revealed by the presence of variants (phase II cells) that appeared on 4- to 5-week-old plantlets. To localize precisely these phase II cells on the root system, roots were divided into three parts: basal, median, and apical zones. We observed an increase in the proportion of variants over time (Table 1). Phase II cells were particularly localized on secondary roots and on root tips where they represented up to $50 \%$ of total CFU of $P$. brassicacearum NFM421 (Table 1). The ability of bacteria to colonize apical roots depends in part on their motile capacities; therefore, we compared the motility and the surface protein content of both variants.

\section{Flagellin characterization.}

Sodium dodecyl sulfate-polyacrylamide gel electrophoresis analysis of surface proteins extracted from phase I and II cells of $P$. brassicacearum NFM421 revealed a major band with an apparent molecular weight of $35 \mathrm{kDa}$; this protein was signifi-

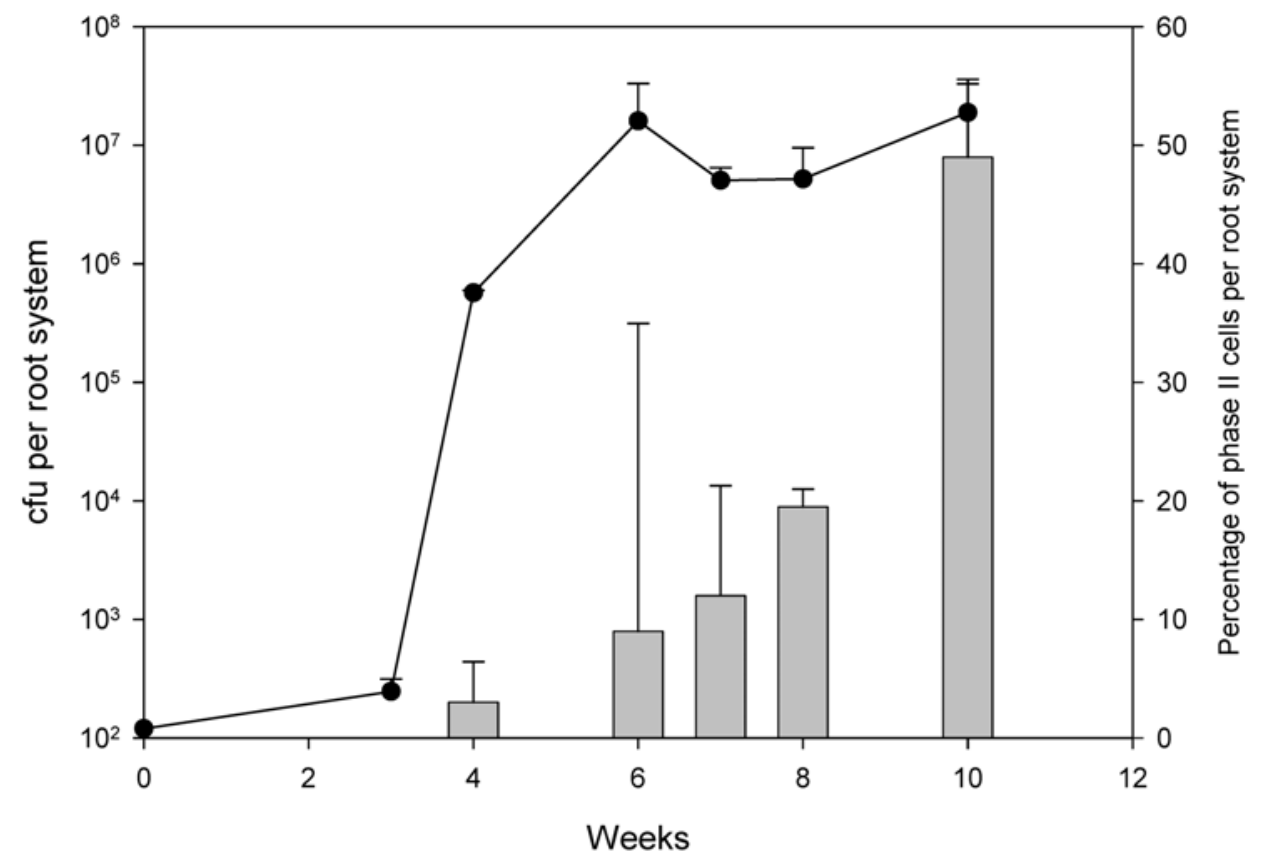

Fig. 1. Kinetics of root colonization of Arabidopsis thaliana seedlings by Pseudomonas brassicacearum NFM421. Curve indicates the number of bacteria associated with the roots over time (log CFU per root system) (left). Histograms indicate the percentage (number of phase II cells/number of phase I + phase II) of phase II cells that appeared over time (right).

Table 1. Phenotypic variation of strain NFM 421 during Arabidopsis thaliana root colonization ${ }^{\mathrm{a}}$

\begin{tabular}{llcc}
\hline Root compartment & 5-week-old seedlings & 7-week- old seedlings & 10-week-old seedlings \\
\hline Basal & $4 \%\left(0.20 \pm 0.01 \times 10^{6}\right)$ & $9 \%\left(0.50 \pm 0.01 \times 10^{6}\right)$ & $24 \%\left(0.60 \pm 0.01 \times 10^{6}\right)$ \\
Median & $1 \%\left(1.00 \pm 0.05 \times 10^{6}\right)$ & $5 \%\left(3.80 \pm 0.1 \times 10^{6}\right)$ & $52 \%\left(2.20 \pm 0.08 \times 10^{6}\right)$ \\
Apical & $3 \%\left(0.90 \pm 0.05 \times 10^{6}\right)$ & $13 \%\left(1.90 \pm 0.1 \times 10^{6}\right)$ & $51 \%\left(4.50 \pm 0.1 \times 10^{6}\right)$ \\
\hline
\end{tabular}

${ }^{a}$ Percent of phase II variants that appeared over time in different parts of roots are indicated, as well as the total number (including phase I and II cells) of bacteria per centimeter of roots (within brackets). 
cantly more intense in phase II cells, suggesting that this protein was overexpressed in phase II cells (Fig. 2). This $35-\mathrm{kDa}$ protein was identified as flagellin by $\mathrm{N}$-terminal amino acid sequencing. Phase II cells showed a higher swimming and swarming motility than phase I cells on semisolid agar medium supplemented with 10-fold-diluted Bacto tryptic soy broth (TSB) medium (Fig. 2).

\section{Co-localization of $P$. brassicacearum variants on $A$. thaliana roots.}

To determine whether the high colonization capacity of $P$. brassicacearum NFM421 was associated to its ability to generate phase II cells from phase I cells in planta, allowing the spread of the population on the whole root system, co-localization of both phase cells on $A$. thaliana roots was investigated. To this end, phase I cells of $P$. brassicacearum NFM421 were genetically tagged with the green fluorescent protein (GFP) or the red fluorescent protein (RFP). The GFP- or RFP-encoding genes were introduced into phase I cells by using a miniTn5 cassette (Andersen et al. 1998; TolkerNielsen et al. 2000). Because the insertion might modify the bacterial physiology, wild-type and tagged bacteria were

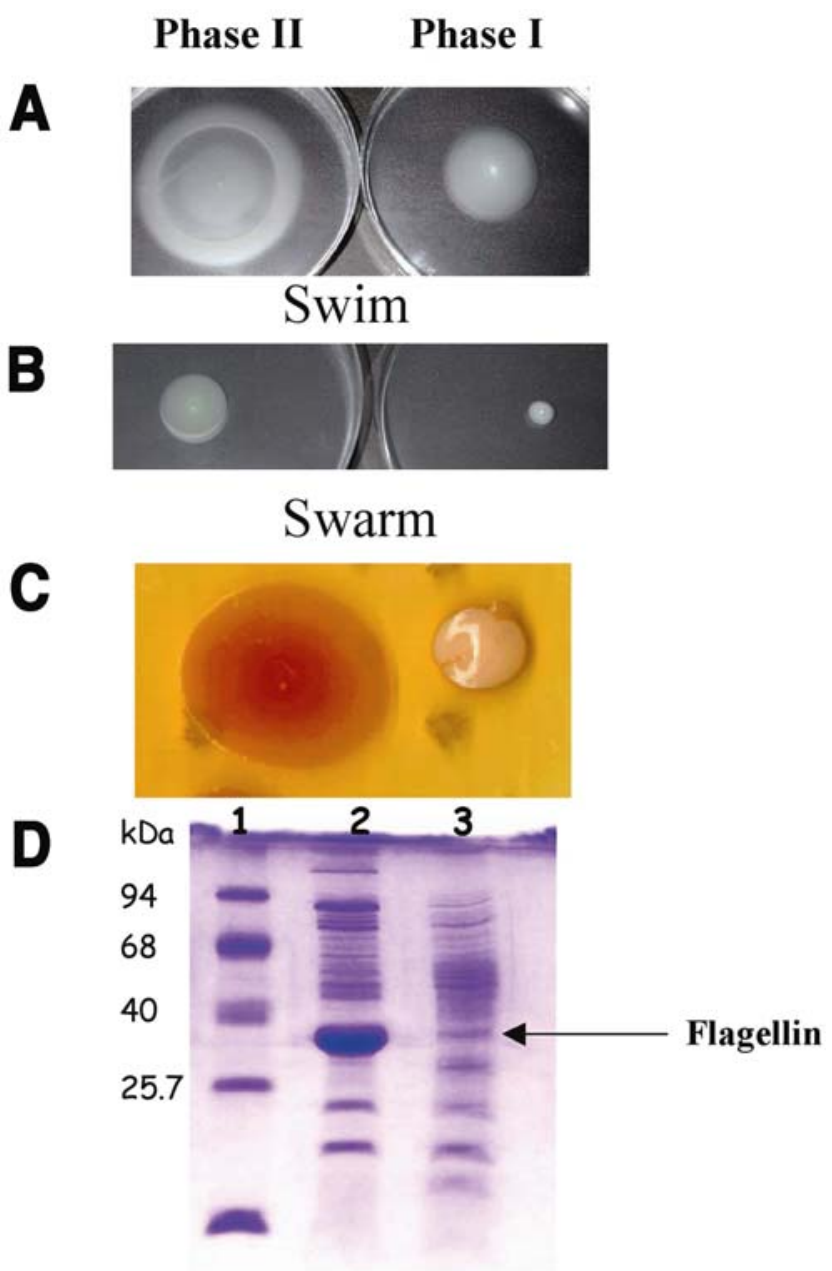

Fig. 2. Motility and flagellin overproduction by phase II cells. A, Swimming motility and B, swarming motility of phase I and phase II cells on 10-fold-diluted tryptic soy broth TSB medium solidified with 0.25 and $0.5 \%$ agar, respectively. C, Colony morphology of phase I (right) and phase II (left) cells grown on Pseudomonas agar F medium. D, Sodium dodecyl sulfate-gel electrophoresis analysis of surface proteins of phase I (lane 3) and phase II (lane 2) cells; molecular size markers are indicated on the left (lane 1), and the major band indicated by an arrow corresponds to the flagellin as identified by $\mathrm{N}$-terminal amino acid sequencing. compared for growth and carbon utilization, using the Biolog system. No difference was evidenced (data not shown). However, to compare the colonization pattern of both phases from $P$. brassicacearum NFM421, we used variants harboring the same insertions at the same chromosomal sites. For this purpose, GFP- and RFP-tagged phase I cells were grown on Bacto Pseudomonas agar $F$ (PAF) medium for 1 week until phenotypic variation took place and phase II cells appeared at the edge of the bacterial colony. Cells from the translucent sectors corresponding to phase II were isolated and observed by using a confocal scanning laser microscope (CSLM) to check whether they were green when isolated from GFPtagged phase I cells and red when isolated from RFP-tagged phase I cells.

A. thaliana seeds were inoculated with a mixture (50:50) of red phase I and green phase II cells (IRIIG) or with a mixture (50:50) of green phase I and red phase II cells (IGIIR). Colonized roots were observed 2 and 3 weeks after seed germination. Co-localization of the two-colored cell phases on $A$. thaliana roots was investigated by using a CSLM.

At all growth stages of the plant, the basal part of the root system was colonized indifferently by both variants, which were able to form mixed microcolonies containing cells from both phases (Fig. $3 \mathrm{C}$ and D). However, with the 3- and 4week-old plantlets, the median part of the primary root system and that of secondary roots essentially were colonized by phase II cells, independently of the fluorescent protein used (Fig. $3 \mathrm{G}-\mathrm{H}$ ). Furthermore, at any stage of root growth, phase II cells were localized on secondary roots and root tips (Fig. $3 \mathrm{E}$ and F), whereas only a few phase I cells were observed at root tips. These experiments were conducted in vitro as well as in natural soil. Phenotypic variation was observed in both situations for up to 4 weeks. Phase II cells showed a high ability to colonize $A$. thaliana roots grown in natural soil, because they represented $21 \pm 5 \%$ of total microflora associated with $A$. thaliana roots 2 weeks after inoculation with phase II cells, and phase I cells represented $20 \pm 4 \%$ in the rhizosphere of plantlets inoculated with phase I cells. These proportions reached $31 \pm 7$ and $24 \pm 4 \%$ for phase I and phase II cells, respectively, within 3 weeks. A 1:1 ratio of both phase cells was used to inoculate seeds and the percentage of each phase cells was determined with 4-week-old seedlings. Phase I cells represented $5 \pm 2 \%$ whereas phase II cells represented $18 \pm 4 \%$ of total cultivable microflora associated with $A$. thaliana roots in natural soil. The high colonization power of NFM421 phase II cells also was confirmed by CSLM observations of roots of $A$. thaliana seedlings grown in Versailles soil (Fig. 4).

\section{Consequences of $A$. thaliana root colonization by $P$. brassicacearum variants.}

Phenotypic variation seems to be essential for the colonization of the whole root system, because this phenomenon occurred in natural soil. Moreover, when A. thaliana seeds were inoculated by phase I or phase II cells of strain NFM421, both phases were able to colonize the plant roots in vitro and in soil. However, only phase I cells were found to modify the root architecture by forming a more branched and shorter root system. Actually, only phase I cells were able to produce, in vitro, indole-3-acetic acid (IAA), indole-3-ethanol, and indole3-lactic acid (Achouak et al. in press).

\section{DISCUSSION}

\section{Phenotypic variation in $P$. brassicacearum.}

In $P$. brassicacearum NFM421, phenotypic variation occurred after 5 days of growth on rich media. Variants or 
phase II cells appeared on the edge of phase I colonies and formed colonies larger than wild-type ones. This larger colony size was not a consequence of rapid growth, because the generation time of these variants in liquid medium was not significantly different from that of phase I cells, and because the colony size of the wild type did not increase over time. The larger colonies formed by phase II cells were due to their higher motility on solid surfaces, allowing the bacteria to colonize new sites where nutrients were available. Reversion of phase II cells with restoration of phase I cells phenotypes, such as colony morphology and exoenzyme activities, was observed on 4-week-old cultures.

In this study, we described the occurrence of phenotypic variation of the rhizobacterium $P$. brassicacearum NFM421 during $A$. thaliana root colonization, and the role of this phenomenon in the rhizosphere competence of this bacterial species. It is worth noting that $P$. brassicacearum was isolated as the major root-colonizing bacterium of $A$. thaliana and $B$. napus roots.

\section{Phenotypic variation of $P$. brassicacearum occurs during $A$. thaliana root colonization.}

Phenotypic variation was shown to take place during alfalfa rhizosphere colonization by $P$. fluorescens F113 (SánchezContreras et al. 2002). In the case of $P$. brassicacearum, phenotypic variation occurred within 4 to 5 weeks after seed germination of $A$. thaliana. Phase II cells, which are much more motile than phase I cells, were localized on the whole root system and especially at the apical part of roots. As the root system grows, the basal part becomes older and is likely to release less exudate. The quantity and probably the quality of root exudates might trigger the phenotypic variation mechanism, resulting in the apparition of phase II cells that are able to move and colonize new sites on the roots where exudation release is more active. Moreover, the data indicated that the fraction of the population that became more motile through phenotypic variation was dependent on plant root environmental conditions. Phase II cells were more stable than phase I cells, and revertants were obtained in pure cultures at low fre-

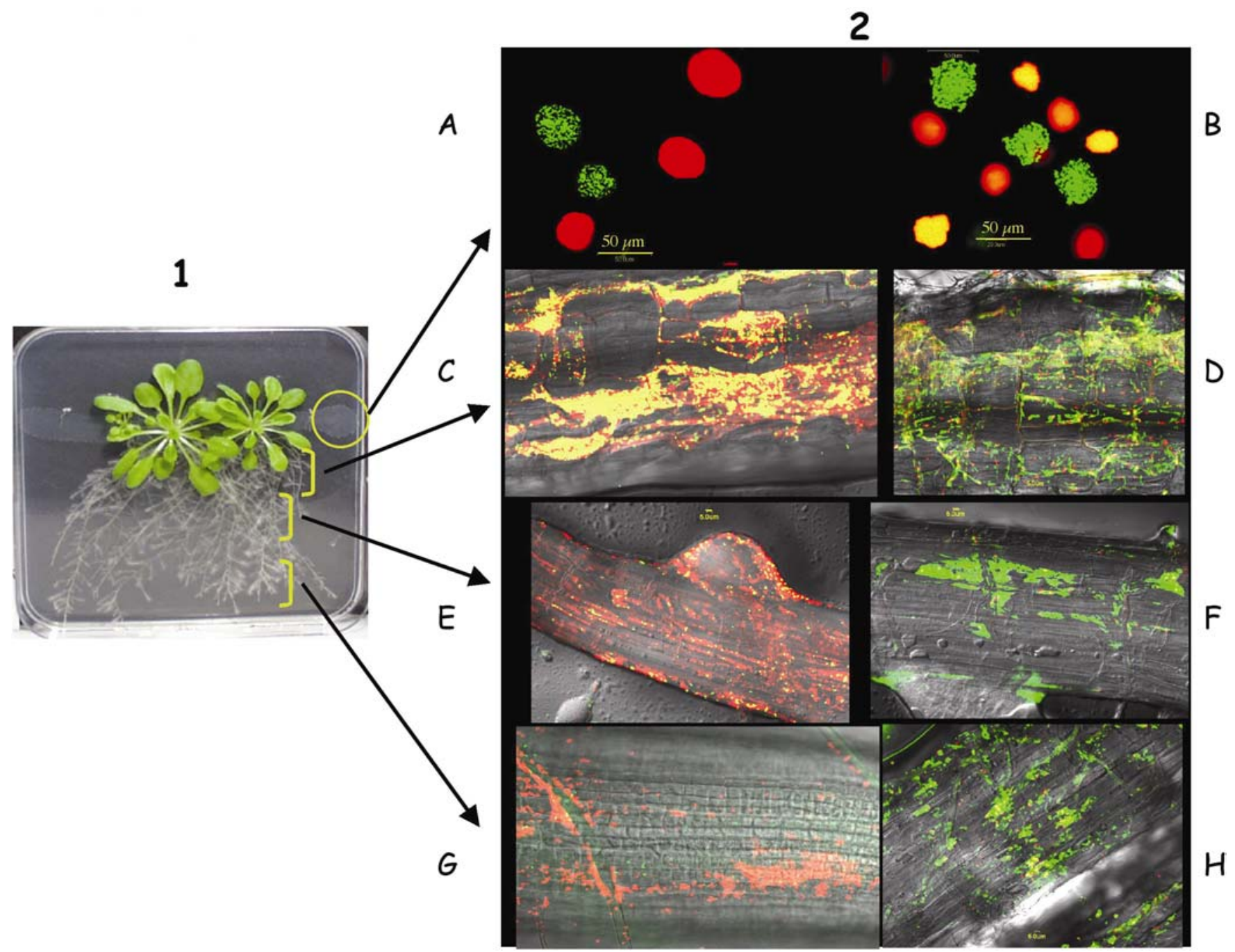

Fig. 3. Colonization assay system. Confocal scanning laser microscope photomicrographs of spatial distribution of phase I and phase II cells of NFM421 on Arabidopsis thaliana roots of 3-week-old seedlings. A, C, E, and $\mathbf{G}$, Co-localization of phase I cells tagged with $g f p$ and phase II cells tagged with $r f p$; $\mathbf{B}$, $\mathbf{D}, \mathbf{F}$, and $\mathbf{H}$, green phase I and red phase II cells (IGIIR) and red phase I and green phase II cells (IRIIG), and co-localization of phase I cells tagged with $r f p$ and phase II cells tagged with $g f p$ :IRIIG. A and B, Inoculation site (agar band). A, microcolonies formed by the co-inoculation of IGIIR cells and $\mathbf{B}$, microcolonies formed by IRIIG cells. $\mathbf{C}$ and $\mathbf{D}$, IGIIR and IRIIG, respectively, colonizing the basal part of $A$. thaliana roots, $\mathbf{E}$ and $\mathbf{F}$ on the median part of roots and $\mathbf{G}$ and $\mathbf{H}$ at the apical part of roots. $\mathbf{C}, \mathbf{D}$, and $\mathbf{E}$, Mixed microcolonies containing both phases are observed; when both green and red fluorescence are present, the two colors together appear yellow in an overlay. The scale bar shown in E and F (indicating $5 \mu \mathrm{m}$ ) also is valid for $\mathrm{C}, \mathrm{D}, \mathrm{G}$, and $\mathrm{H}$. The images were taken with a Olympus Scanning Confocal microscope. Laser excitation was at $488 \mathrm{~nm}$ wavelength for green fluorescent protein and at $568 \mathrm{~nm}$ for red fluorescent protein, and emission of red and green fluorescence were collected with a photomultiplier in the confocal. 
quency. Phenotypic variation or reversion is likely to be a random process; however, there are cases where the rate of phenotypic switching is controlled by environmental factors (Hallet 2001) (e.g., the environment controls the reversion frequency via a regulatory protein $[\mathrm{PvrR}]$ in $P$. aeruginosa) (Drenkard and Ausubel 2002).

\section{Colonization pattern of $\boldsymbol{P}$. brassicacearum variants.}

Co-localization of both phase cells of $P$. brassicacearum NFM421 during root colonization illustrated the higher ability of phase II cells to colonize the whole root system. It is worth noting that co-localization experiments were realized with 2to 3-week-old seedlings, to avoid the occurrence of phenotypic variation of phase I to phase II cells, which normally takes place 4 to 5 weeks after seed germination.

Optimal colonization by P. chlororaphis PCL1391 (Dekkers et al. 1998) and biocontrol traits of certain Pseudomonas strains (van den Broek et al. 2003) were shown to be impaired by phenotypic variation. In the present study, we have shown that $P$. brassicacearum NFM421 variants were not affected in

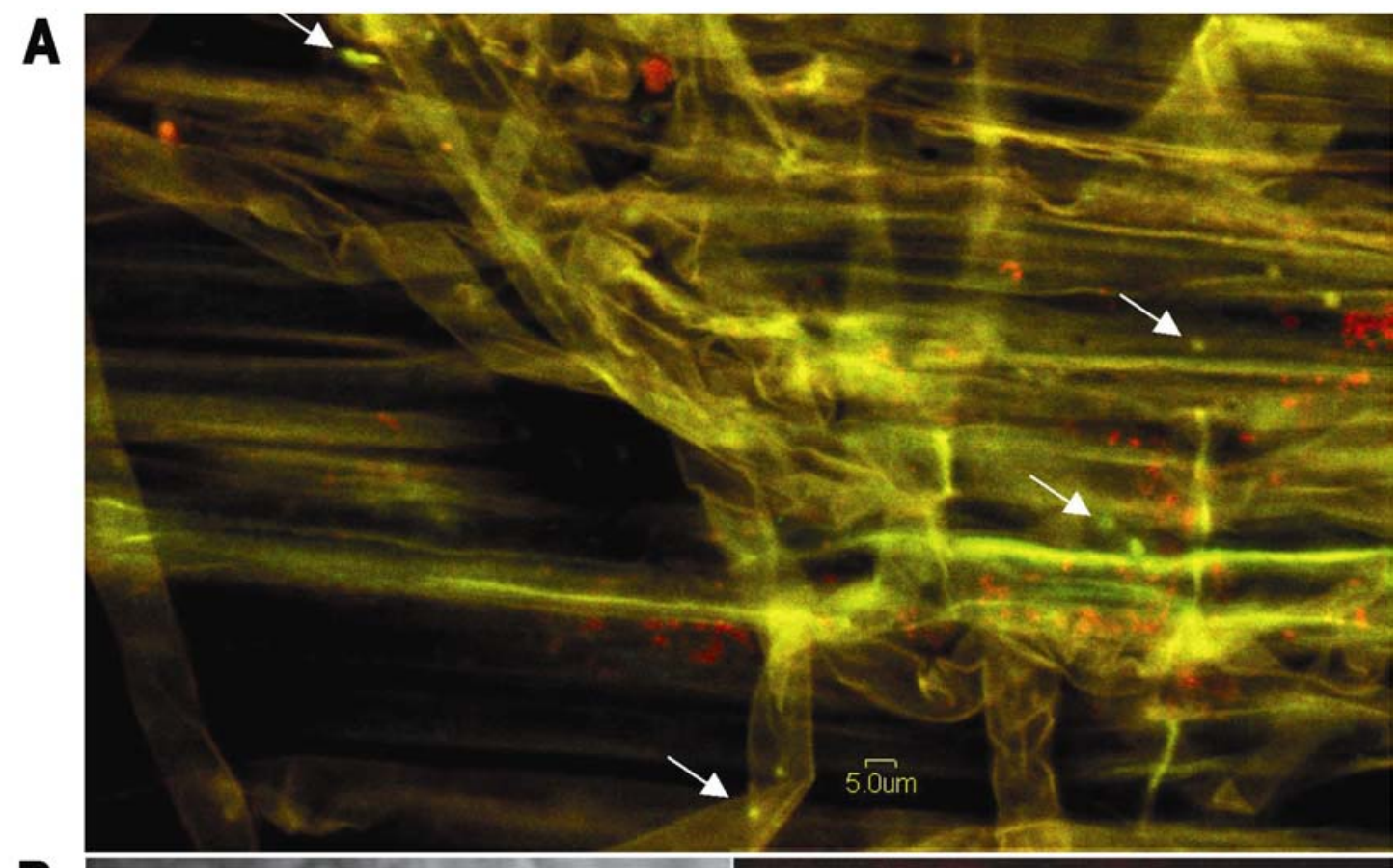

B

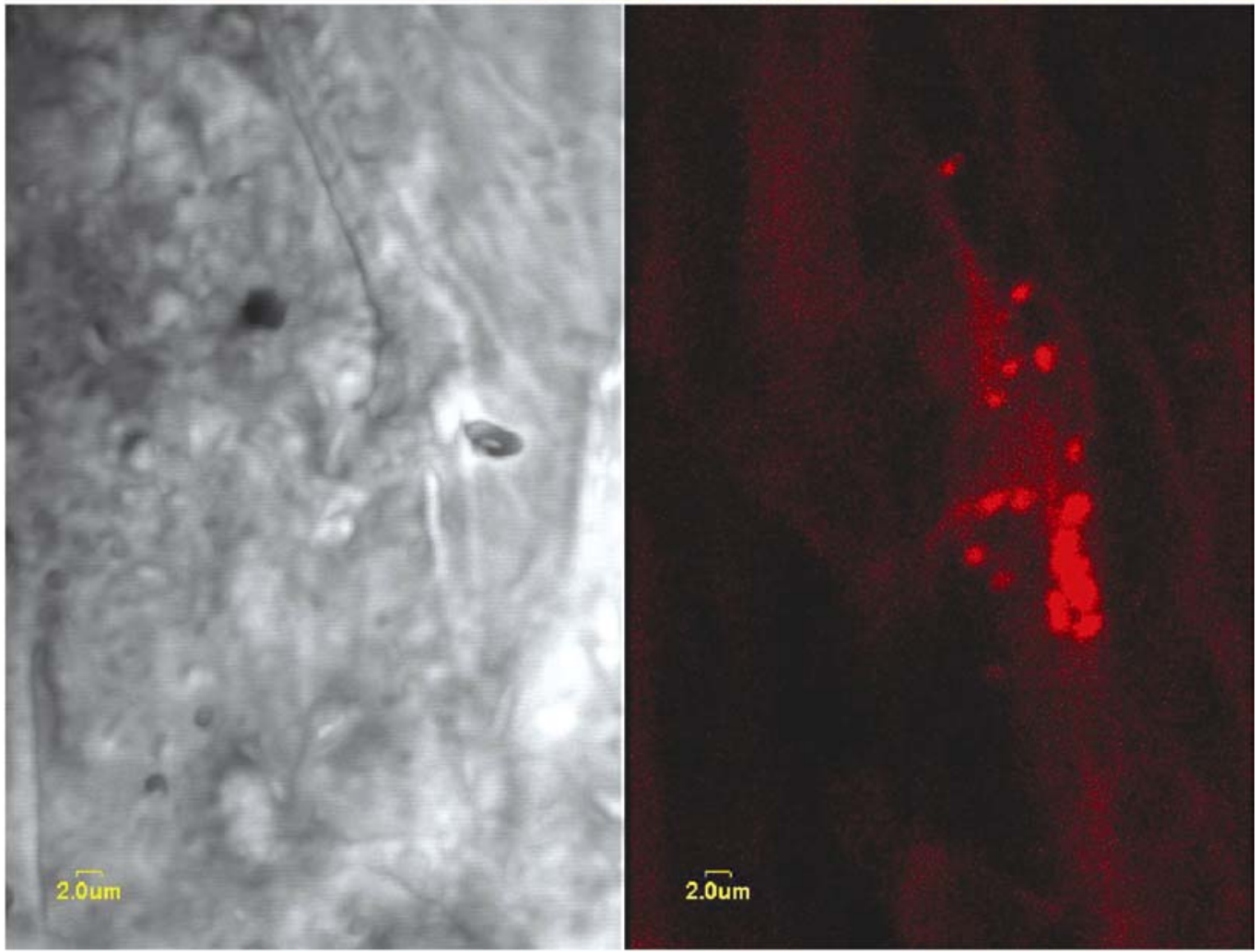

Fig. 4. Confocal scanning laser microscope examination of Arabidopsis thaliana roots colonization in natural soil. A, Median part of roots colonized by phase I green and phase II red fluorescent protein-tagged bacteria (IGIIR). White arrows indicate green fluorescent protein-tagged phase I cells. B, Median roots colonized by red fluorescent protein-tagged phase II cells. 
the rhizosphere competence, because they represented up to $24 \%$ of total cultivable microflora associated with $A$. thaliana roots when seeds were inoculated with phase II cells and grown in natural soil. However, we previously showed that these variants did lose the ability to modify $A$. thaliana root architecture, because genes of bacterial auxin production are under phenotypic variation control (Achouak et al. in press). The expression of auxin-encoding genes probably is not necessary for the survival of the bacterial population; however, their ability to move faster on root system to colonize more interesting sites where nutrients are available is an important survival trait.

Phenotypic variation might be used to modulate the overall adaptability and fitness of a bacterial population and, under certain circumstances, to express preferential phenotypes in relation to specific conditions. We previously investigated the expression of the operon encoding lipase, protease, secretion machinery, and serine protease in $P$. brassicacearum by construction of transcriptional lac $Z$ gene fusions of the operon promoter. Promoter activity was detected only in phase I cells, indicating a regulation of this operon at a transcriptional level (Chabeaud et al. 2001). It may be advantageous for the organism to be able to turn off protein expression in environments where such proteins are not required and to overexpress others, such as flagellin, in order to spread in an ecological niche like the rhizosphere. Swarming and swimming motility in different Xenorhabdus nematophilus strains (Givaudan et al. 1995), and in P. fluorescens F113 (Sánchez-Contreras et al. 2002) were shown to be influenced by phase variation. Motility in $X$. nematophilus is controlled by the $f l h D C$ operon, and is involved in the infectious process in insects (Givaudan and Lanois 2000).

Phenotypic variation of $P$. brassicacearum is expected to correspond to a strategy allowing the colonization of the whole root system, which may explain, at least partly, the high colonization capacity of this bacterial species. These results suggest that phenotypic variation may provide insight into the interaction of $P$. brassicacearum with its Brassicaceae host. Further investigations are now in process to elucidate the mechanism driving the phenotypic variation.

\section{MATERIALS AND METHODS}

\section{Bacterial strains, plasmids, and growth conditions.}

The bacterial strains and plasmids used in this study are listed in Table 2. P. brassicacearum NFM421 was grown at $30^{\circ} \mathrm{C}$ in 10 -fold-diluted TSB (TSB/10) or PAF medium (Difco Laboratories, Detroit). Escherichia coli strains were grown in Luria-Bertani medium at $37^{\circ} \mathrm{C}$ unless otherwise stated. For growth on plates, media were solidified with Bacto-agar at 15 g liter ${ }^{-1}$ (Difco Laboratories).

Antibiotics for $P$. brassicacearum were added at the following concentrations: ampicillin, $100 \mu \mathrm{g} \mathrm{ml}^{-1}$; rifampicin, 50

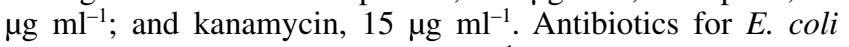
were used at: ampicillin, $100 \mu \mathrm{g} \mathrm{ml}^{-1}$; and kanamycin, $25 \mu \mathrm{g}$ $\mathrm{ml}^{-1}$.

\section{Protein extraction and analysis.}

Bacteria were grown on TSB/10 for $16 \mathrm{~h}$ and washed twice with $0.85 \% \mathrm{KCl}$. The surface proteins were extracted from a bacterial suspension $\left(10^{10} \mathrm{CFU} \mathrm{m} \mathrm{m}^{-1}\right)$ by several passages through a syringe and needle to detach surface appendages. Bacterial cells were removed by centrifugation at $5,000 \times g$ for $5 \mathrm{~min}$., and trichloroacetic acid was added to $5 \%$ (final concentration) to the supernatant, to precipitate proteins at $0^{\circ} \mathrm{C}$ for $1 \mathrm{~h}$. Proteins were pelleted by centrifugation at $10,000 \times g$ for $1 \mathrm{~h}$, then washed with acetone. Surface proteins were submitted to electrophoresis in $12 \%$ acrylamide gels that were stained with Coomassie blue. For amino acid sequence analysis, proteins separated on $12 \%$ acrylamide gels were electrotransferred into polyvinylidene difluoride membranes, which were stained with Coomassie Brilliant Blue G 250, and the band corresponding to the protein of interest was excised and then submitted to automated Edman degradation of the peptide as previously described (Achouak et al. 1995).

\section{Swarm and swim motility assays.}

Swarm motility was determined on plates containing $\mathrm{TSB} / 10$ solidified with agar at $5 \mathrm{~g} \mathrm{liter}^{-1}$, and swim motility on $\mathrm{TSB} / 10$ solidified with agar at $2.5 \mathrm{~g} \mathrm{liter}^{-1}$. Overnight bacterial culture $(1 \mu \mathrm{l})$ was spotted in the middle of swarm and swim plates and then incubated at $30^{\circ} \mathrm{C}$ for $16 \mathrm{~h}$.

\section{Insertion of $g f p$ and dsRed into the chromosome of phase I cells.}

P. brassicacearum NFM421-I::rfp and NFM421-I::gfp were obtained using a PA1/04/03-gfp-T0-T1 (Andersen et al. 1998) and PA1/04/03-RBSIIdsRed-T0-T1 which harbor mini-Tn5 transposons (Tolker-Nielsen et al. 2000). These fusions were transferred to the chromosome of $P$. brassicacearum NFM421

Table 2. Bacterial strains and plasmids used in this study

\begin{tabular}{|c|c|c|}
\hline Strains and plasmids & Relevant phenotypes and characteristics ${ }^{a}$ & Reference \\
\hline \multicolumn{3}{|l|}{ Escherichia coli } \\
\hline HB101 & $\begin{array}{l}\text { F-thi-1 hsdS20 (r- Bm- B) supE44 recA13 ara-14 leuB6 proA2 lacY1 rpsL20 } \\
\text { (Smr) xyl-5 mtl-1 }\end{array}$ & Boyer and Roulland- Dussoix 1969 \\
\hline CC118 ( $\lambda$ pir $)$ & $\begin{array}{l}\text { (ara-leu) araD lacX74 galE galK phoA thi-1 rpsE rpoB argE(Am) recA } \lambda \text { pir } \\
\text { lysogen }\end{array}$ & Herrero et al. 1990 \\
\hline \multicolumn{3}{|c|}{ Pseudomonas brassicacearum } \\
\hline NFM421 & Wild type & Achouak et al. 2000 \\
\hline NFM421-IG & $\begin{array}{l}\text { Phase I NFM421 X HB101(RK600) X CC118 ( } \lambda \text { pir) (pJBA28) } a \text {; NFM 421-I with } \\
\text { a mini-Tn5-Km- PA1/04/03-RBSII-gfpmut } 3 *-T 0-T 1-c a s s e t t e \text { from pJBA28 } \\
\text { randomly inserted into the chromosome; } \text { Rif }^{r} \mathrm{Km}^{\mathrm{r}}\end{array}$ & This study \\
\hline NFM421-IR & 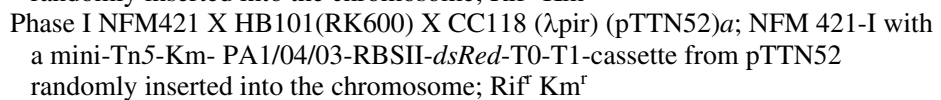 & This study \\
\hline NFM421-IIG & Obtained from NFM421-IG after 5 days' growth on PAF medium & This study \\
\hline NFM421-IIR & Obtained from NFM421-IR after 5 days' growth on PAF medium & This study \\
\hline \multicolumn{3}{|l|}{ Plasmids } \\
\hline pJBA28 & $\mathrm{Ap}{ }^{\mathrm{r}} ; \mathrm{Km}^{\mathrm{r}}$; delivery plasmid for mini-Tn5-Km-PA1/04/03-RBSII-gfpmut3*-T0-T1 & Andersen et al. 1998 \\
\hline pTTN52 & $\mathrm{Ap}^{\mathrm{r}} ; \mathrm{Km}^{\mathrm{r}}$; delivery plasmid for mini-Tn5-Km-PA1/04/03-RBSII-dsRed-T0-T1 & Tolker-Nielsen et al. 2000 \\
\hline pRK600 & Cmr ori ColE1 RK2-Mob1 RK2-Tra1; helper plasmid in triparental matings & Kessler et al. 1992 \\
\hline
\end{tabular}

\footnotetext{
${ }^{\mathrm{a}} \mathrm{Ap}^{\mathrm{r}}, \mathrm{Cm}^{\mathrm{r}}, \mathrm{Rif}^{\mathrm{r}}$, and $\mathrm{Km}^{\mathrm{r}}=$ resistance to ampicillin, chloramphenicol, rifampin, and kanamycine, respectively.
} 
by triparental mating as described by Herrero and associates (1990). E. coli CC118 $\lambda$ pir (pSM1696) and HB101(pRK600) were used as donor and helper strains, respectively. Phase II cells with the same chromosomal insertions were obtained from NFM421-I::rfp and NFM421-I::gfp after growth on PAF (Difco Laboratories) medium for 1 week. The green fluorescent derivatives were designated NFM421-IG and NFM421IIG and the red fluorescent derivatives were designated NFM421-IR and NFM421-IIR.

\section{Microscopy and image analysis.}

Root colonization observations were performed on a CSLM (Olympus) equipped with an argon-krypton laser, detectors, and filter sets for simultaneous monitoring of GFP and RFP. Shadow projections and optical sections were generated using the Fluoview software package. Images were processed further for display by using Photoshop software (Adobe, Mountain View, CA, U.S.A.).

\section{In vitro root colonization experiments.}

A suspension of $10^{2} \mathrm{CFU}$ of NFM421 phase I cells was used for kinetics of root colonization experiments, and an equal mixture of $10^{3} \mathrm{CFU}$ of NFM421-IG and NFM421-IIR and an equal mixture of NFM421-IR and NFM421-IIG were used for co-localization assays. Bacterial suspensions were added to $1 \mathrm{ml}$ of agar at $5 \mathrm{~g}^{\text {liter }}{ }^{-1}$ containing half-strength Hoagland medium (Arnon and Hoagland 1940) and poured as a band where surface-sterilized $A$. thaliana Col seed were sown (5 sterile seeds per plate) on half-strength Hoagland medium and $0.8 \%$ phytagel (Sigma, St. Louis). The squared dishes (15 by $15 \mathrm{~cm})$ were sealed with micropore tape $(3 \mathrm{M}$, St. Paul, MN, U.S.A.) and incubated vertically at $22^{\circ} \mathrm{C}$ with $16 \mathrm{~h}$ of light and $18^{\circ} \mathrm{C}$ at night (approximately 100 photons $\mathrm{m}^{-2} \mathrm{~s}^{-1}$ ) per day. At different stages of plant growth, roots were divided into three compartments (1.5- to $2-\mathrm{cm}$ basal part, 1-cm apical part, and variable lengths of median part) over time; roots were crushed and bacteria enumerated by plating serial dilutions on $\mathrm{TSB} / 10$ medium containing skimmed milk to visualize protease activity, which is specific for phase I cells. A root colonization pattern for each phase cells also was evidenced by CSLM observations.

\section{Root colonization experiments in soil.}

Root colonization experiments also were conducted in soil, which is an Eutric Cambisol collected from a Versailles site (INRA) in May 2003 from the upper $30 \mathrm{~cm}$ of the soil profile, air dried for 1 week, and passed through a $0.4-\mathrm{cm}$ mesh screen prior to use. Soil was inoculated with phase I or phase II cells of $P$. brassicacearum NFM421 at a rate of $10^{7} \mathrm{CFU} / \mathrm{g}$ of soil. A. thaliana Col seed were surface sterilized and sown into the soil in 300-ml polyvinyl chloride pots containing $100 \mathrm{~g}$ of soil; plants were harvested after 2,3 , or 4 weeks of incubation in growth chambers with controlled atmosphere in the same conditions as described above.

Roots were washed with sterile ultrapure water and then observed using a confocal scanning laser microscope, and population sizes of introduced bacteria were determined by dilution plating of ground roots.

Root-adhering bacteria were counted on the whole root system. For that purpose, three root systems per treatment were washed vigorously in $100 \mathrm{ml}$ of ultrapure water and then crushed separately, and root-adhering bacteria were enumerated on TSB/10 containing skimmed milk with or without kanamycin $\left(25 \mu \mathrm{g} \mathrm{ml}^{-1}\right)$. Colonies grown on media containing antibiotics were observed for fluorescence, and proportion of each phase was determined compared with total enumerated bacteria on media in the absence of antibiotic.

\section{ACKNOWLEDGMENTS}

This research was supported by research grant (CNRS) Programme International de Cooperation Scientifique numbers 931 and 848. We gratefully acknowledge the supply of $g f p$ and $r f p$ constructs by P. Ragas and T. Tolker-Nielsen. We are grateful to C. Merlin and to M. Sullivan for manuscript revision.

\section{LITERATURE CITED}

Achouak W., Conrod S., Robert S., and Heulin T. Phase variable effects of Pseudomonas brassicacearum on Arabidopsis thaliana root architecture. B. Lugtenberg, I. Tikhonovich, and N. Provorov, eds. Biology of Molecular Plant-Microbe Interactions, Volume 4 Proceedings of the 2003 International Society-Molecular Plant-Microbe Interactions Symposium. St. Petersburg, Russia. In press.

Achouak W., De Mot R., and Heulin T., 1995. Purification and partial characterization of an outer membrane protein involved in the adhesion of Rahnella aquatilis to wheat roots. FEMS (Fed. Eur. Microbiol. Soc.) Microbiol. Ecol. 16:19-24.

Achouak W., Sutra, L., Heulin, T., Meyer, J.-M., Fromin, N., Degraeve, S., Christen, R., and Gardan, L. 2000. Description of Pseudomonas brassicacearum sp. nov. and Pseudomonas thivervalensis sp. nov., two rootassociated bacteria isolated from Arabidopsis thaliana and Brassica napus. Int. J. Syst. Evol. Microbiol 50:9-18.

Andersen, J. B., Sternberg, C., Poulsen, L. K., Bjorn, S. P., Givskov, M., and Molin, S. 1998. New unstable variants of green fluorescent protein for studies of transient gene expression in bacteria. Appl. Environ. Microbiol. 64:2240-2246.

Arnon, D. I., and Hoagland, D. R. 1940. Crop production in artificial culture solutions and in soils with special reference to factors influencing yields and absorption of organic nutrients. Soil Sci. 50:463-483.

Barbour, A. G., Tessier, S. L., and Stoenner, H. G. 1982. Variable major proteins of Borrellia hermsii. J. Exp. Med. 156:1312-1324.

Boyer, H. W., and Roulland-Dussoix, D. 1969. A complementation analysis of the restriction and modification of DNA in Escherichia coli. J. Mol. Biol. 41:459-472.

Chabeaud, P., De Groot, A., Heulin, T., Bitter, W., Tommassen, J., and Achouak, W. 2001. Phase-variable expression of an operon encoding extracellular alkaline protease, serine protease homologue and lipase in Pseudomonas brassicacearum. J. Bacteriol. 183:2117-2120

Cutri, S. S., Macaulay, B. J., and Roberts, W. P. 1984. Characteristics of pathogenic non-fluorescent (smooth) and non-pathogenic fluorescent (rough) form of Pseudomonas tolaasii and Pseudomonas gingeri. J. Appl. Bacteriol. 57:291-298.

Dekkers, L. C., Phoelich, C. C,. Van der Fits, L., and Lugtenberg, B. J. J. 1998. A site-specific recombinase is required for competitive root colonization by Pseudomonas fluorescens WCS365. Proc. Natl. Acad. Sci. U.S.A. 95:7051-7056.

Déziel, E., Comeau, Y., and Villemur, R. 2001. Initiation of biofilm formation by Pseudomonas aeruginosa 57RP correlates with emergence of hyper-inflation and highly adherent phenotypic variants deficient in swimming, swarming, and twitching motilities. J. Bacteriol. 183:11951204.

Drenkard, E., and Ausubel, F. M. 2002. Pseudomonas biofilm formation and antibiotic resistance are linked to phenotypic variation. Nature 416:740-743.

Givaudan, A., Baghdiguian, S., Lanois, A., and Boemare, N. 1995. Swarming and swimming changes concomitant with phase variation in Xenorhabdus nematophilus. Appl. Environ. Microbiol. 61:14081413.

Givaudan A., and Lanois, A. 2000. flhDC, the flagellar master operon of Xenorhabdus nematophilus: Requirement for motility, lipolysis, extracellular hemolysis, and full virulence in insects. J. Bacteriol. 182:107-115.

Grewal, S. I. S., Han, B., and Johnstone, K. 1995. Identification and characterization of a locus which regulates multiple functions in Pseudomonas tolaasii, the cause of brown blotch disease of Agaricus bisporus. J. Bacteriol. 177:4658-4668.

Hallet, B. 2001. Playing Dr Jekyll and Mr Hyde: combined mechanism of phase variation in bacteria. Curr. Opin. Microbiol. 4:570-581.

Henderson, I. R., Owen, P., and Nataro, J. P. 1999. Molecular switches- the $\mathrm{ON}$ and OFF of bacterial phase variation. Mol. Microbiol. 33:919-932.

Herrero, M., V. de Lorenzo, and Timmis, K. 1990. Transposon vectors containing non antibiotic resistance selection markers for cloning and stable chromosomal insertion of foreign genes in gram-negative bacteria. J. Bacteriol. 172:6557-6567

Hosking, S. L., Craig, J. E., and High, N. J. 1999. Phase variation of lic1 A, lic2A and lic3A in colonization of the nasopharynx, bloodstream 
and cerebrospinal fluid by Haemophilus influenzae type b. Microbiology 145:3005-3011.

Howe, T. R., LaQuier, F. W., and Barbour, A. G. 1986. Organization of genes encoding two outer membrane proteins of the Lyme disease agent Borrelia burgdorferi within a single transcriptional unit. Infect. Immun. 54:207-212.

Kessler, B., de Lorenzo, V., and Timmis, K. N. 1992. A general system to integrate $l a c Z$ fusions into the chromosomes of gram negative eubacteria: regulation of the $P m$ promoter in the TOL plasmid studied with all controlling elements in monocopy. Mol. Gen. Genet. 233:293-301.

Makino, S., van Putten, J. P., and Meyer, T. F. 1991. Phase variation of the opacity outer membrane protein controls invasion by Neisseria gonorrhoeae into human epithelial cells. EMBO (Eur. Mol. Biol. Organ.) J. 10:1307-1315.

Miller, K. J., and Wood, J. M. 1999. Osmoadaptation by rhizosphere bacteria. Annu. Rev. Microbiol. 50:101-136.

Pearce, U. B., and Stocker, B. A. 1967. Phase variation of flagellar antigens in Salmonella: abortive transduction studies. J. Gen. Microbiol. 49:335-349.

Persello-Cartieaux F., David, P., Sarrobert, C., Achouak, W., Robaglia, C., and Nussaume, L. 2001. Utilization of mutants to analyze the interaction between Arabidopsis thaliana and its naturally root-associated Pseudomonas. Planta 212:190-198.

Rainey, P. B., and Travisano, M. 1998. Adaptive radiation in heterogene- ous environment. Nature 394:69-72.

Ross, I., Alami Y., Harvey, P. R., Achouak, W., and Ryder, M. 2000. Genetic diversity and biological control activity of novel species related to pseudomonads isolated from wheat field soils in South Australia. Appl. Environ. Microbiol. 66:1609-1616.

Sánchez-Contreras, M., Martin, M., Villacieros, M., O’Gara, F., Bonilla I., and Rivilla, R. 2002. Phenotypic selection and phase variation occur during Alfalfa root colonization by Pseudomonas fluorescens F113. J. Bacteriol. 184:1587-1596.

Shapiro, J. A. 1986. Control of Pseudomonas putida growth on agar surfaces. Pages 27-69 in: The Bacteria, vol. X. J. R. Sokatch, ed Academic Press, New York.

Tolker-Nielsen T, Brinch, U. C., Ragas, P. C., Andersen, J. B., Jacobsen, C. S., and Molin, S. 2000. Development and dynamics of Pseudomonas sp. biofilms. J Bacteriol. 182:6482-6489.

Van den Broek, D., Chin-A-Woeng, T. F., Eijkemans, K., Mulders, I. H., Bloemberg, G. V., and Lugtenberg, B. J. 2003. Biocontrol traits of Pseudomonas spp. are regulated by phase variation. Mol. PlantMicrobe Interact. 16:1003-1012.

Zhang, Q., and Wise, K. S. 1996. Molecular basis of size and antigenic variation of a Mycoplasma hominis adhesin encoded by divergent vaa gene. Infect. Immun. 64:2737-2744.

Zhang, J. R., Hardham, J. M., Barbour, A. G., and Norris, S. J. 1997. Antigenic variation in Lyme disease borreliae by promiscuous recombination of VMP-like sequence cassettes. Cell. 89:275-285. 